\title{
Tingkat Pengetahuan Wanita Usia Reproduksi tentang Kanker Leher Rahim di Kota Manado
}

\author{
${ }^{1}$ Ulung Prayogo \\ ${ }^{2}$ John J. E. Wantania \\ ${ }^{2}$ Frank M. M. Wagey
}

\begin{abstract}
${ }^{1}$ Program Studi Pendidikan Dokter Fakultas Kedokteran Universitas Sam Ratulangi Manado
${ }^{2}$ Bagian Obstetri dan Ginekologi, Fakultas Kedokteran, Universitas Sam Ratulangi Manado Email: Prayogo_ulung@yahoo.co.id
\end{abstract}

\begin{abstract}
Cervical cancer is a malignant disease on the area of cervix and its common symptom is abnormal vaginal bleeding. Women of low economics level have higher risk to suffer from cervical cancer because they do not have professional health service, less education of cervical cancer and its prevention; therefore, cervical cancer cases can not be early detected. This study was aimed to identify the knowledge level of reproductive women about cervical cancer in Manado. This was a quantitative descriptive study with a cross sectional design. This study used questionnaire which had be validated on 50 reproductive women and data were processed by using SPSS. The results showed 288 respondents that fulfilled the inclusion criteria. Of the total 288 respomdemts, 141 (49\%) had high level of knowledge about cervical cancer; 132 people $(45,8 \%)$ had moderate level of knowledge; and 15 people $(5,2 \%)$ had low level of knowledge. Conclusion: In this study, most reproductive women had high level of knowledge about cervical cancer.
\end{abstract}

Keywords: knowledge, reprodutive women, cervical cancer

\begin{abstract}
Abstrak: Kanker leher rahim adalah keganasan di daerah leher rahim, yang umumnya memberikan gejala perdarahan per vagina yang abnormal. Wanita dengan tingkat ekonomi rendah berisiko tinggi terkena kanker leher rahim karena tidak adanya akses pada pelayanan kesehatan yang memadai, ketidaktahuan atau rendahnya pengetahuan mengenai kanker leher rahim dan pencegahannya yang menyebabkan kanker leher rahim tidak terdeteksi secara dini. Penelitian ini bertujuan untuk mengidentifikasi gambaran tingkat pengetahuan wanita usia reproduksi tentang kanker leher rahim di Kota Manado. Jenis penelitian ialah deskriptif kuantitatif dengan desain potong lintang dan dilakukan di Puskesmas Bahu, Puskesmas Tuminting, dan Puskesmas Wenang Kota Manado. Penelitian ini menggunakan kuisioner yang telah divalidasi pada 50 wanita usia reproduksi dan diolah menggunakan SPSS. Hasil penelitian mendapatkan sebanyak 288 responden yang memenuhi kriteria inklusi. Responden yang memiliki tingkat pengetahuan baik tentang kanker leher rahim sebesar 141 orang (49\%), berpengetahuan cukup 132 orang $(45,8 \%)$, dan berpengetahuan kurang 15 orang $(5,2 \%)$.
\end{abstract}

Simpulan: Dalam studi ini, sebagian besar wanita usia reproduksi memiliki tingkat pengetahuan baik tentang kanker leher rahim.

Kata kunci: pengetahuan, wanita usia reproduksi, kanker leher rahim

Kanker leher rahim atau kanker serviks adalah keganasan di daerah leher rahim, yang umumnya memberikan gajala perdarahan per vagina yang abnormal, meskipun dalam beberapa kasus mungkin tidak terdapat gejala yang menonjol sampai didapatkan kanker stadium lanjut. ${ }^{1}$ Kanker serviks merupakan salah satu penyakit yang mematikan bagi wanita di negara maju maupun berkembang. ${ }^{2}$ Pada tahun 2016, 
American Cancer Society memprediksi kasus kanker serviks di U.S pada tahun 2016 terdapat sekitar 12.990 kasus baru akan didiagnosis dan sekitar 4.120 wanita meninggal dikarenakan kanker serviks. ${ }^{3}$

Menurut data International Agency for Research on Cancer (IARC) 2015, kanker leher rahim merupakan kanker terbesar ke4 pada wanita diseluruh dunia. Prevalensi kejadian kanker leher rahim di seluruh dunia ialah sekitar 528.000 kasus baru kanker leher rahim pada tahun 2012 dengan 266.000 kematian penyebab kanker leher rahim di seluruh dunia. Di Indonesia kanker leher rahim merupakan kanker dengan prevalensi tertinggi yaitu sekitar 0,8\% atau sekitar 98.692 penderita kanker leher rahim di Indonesia (Kemenkes RI, 2015). ${ }^{4}$

Program-program skrining saat ini terlaksana atas kesadaran para wanita untuk melakukan pemeriksaan rutin serta tindak lanjut dari para pakar kesehatan. Metode Pap's smear merupakan salah satu tindakan awal untuk mendeteksi dini kanker leher rahim bagi kaum wanita. Selain itu, ada juga pemeriksaan Inspeksi Visual Asam Asetat (IVA) yaitu pemeriksaan dengan asam asetat $4 \% .5$

Pemerintah menganjurkan kepada wanita berusia 35-55 tahun yang masih aktif melakukan hubungan seksual untuk melakukan deteksi dini kanker leher rahim setiap 5 tahun sekali. Wanita-wanita yang tingkat ekonominya rendah berisiko tinggi terkena kanker leher rahim karena mereka tidak mempunyai akses pada pelayanan kesehatan yang memadai, untuk melakukan Pap's smear dan tes IVA secara rutin, ketidaktahuan atau rendahnya pengetahuan seseorang mengenai penyakit kanker leher rahim dan pencegahannya dapat menyebabkan kanker leher rahim tidak terdeteksi secara dini. Bila pengetahuan seorang wanita tentang pencegahan kanker leher rahim luas maka haal itu akan menimbulkan rasa kepercayaan terhadap deteksi dini kanker leher rahim. ${ }^{6}$

Penelitian ini bertujuan untuk mengidentifikasi gambaran tingkat pengetahuan wanita usia reproduksi tentang kanker leher rahim di Kota Manado. Penelitian ini diharapkan dapat menjadi acuan bagi tenaga professional kesehatan mengenai tingkat pengetahuan wanita usia reproduksi tentang kanker leher rahim di Kota Manado.

\section{METODE PENELITIAN}

Jenis penelitian ini ialah deskriptif kuantitatif dengan desain potong lintang menggunakan data primer dari kuisioner yang sebelumnya telah divalidasi menggunakan Statistical package for the social science (SPSS).

Penelitian ini dilakukan di Puskesmas Bahu, Puskesmas Tuminting dan Puskesmas Wenang Kota Manado. Pada penelitian ini digunakan 288 sampel yang telah ditentukan berdasarkan metode Lameshow. ${ }^{7}$ Untuk pengolahan data digunakan aplikasi SPSS.

\section{HASIL PENELITIAN}

Penelitian ini dilakukan di Puskesmas Bahu, Tuminting, dan Wenang. Sebagian besar responden berusia 20-29 tahun yaitu sebanyak 112 orang $(38,9 \%)$ dan yang paling sedikit berusia $<20$ tahun yaitu 22 orang $(7,6 \%)$.

Tabel 1. Karakteristik berdasarkan usia

\begin{tabular}{ccc}
\hline Usia & $\mathbf{N}$ & $\mathbf{\%}$ \\
\hline$<20$ & 22 & 7,6 \\
$20-29$ & 112 & 38,9 \\
$30-39$ & 88 & 30,6 \\
$>40$ & 66 & 22,9 \\
Total & 288 & 100 \\
\hline
\end{tabular}

Berdasarkan pendidikan, sebagian besar responden berpendidikan SMA yaitu sebanyak 151 orang $(52,4 \%)$ dan yang paling sedikit berpendidikan SD yaitu sebanyak 3 orang $(1,0 \%)$ (Tabel 2 ).

Berdasarkan pekerjaan, sebagian besar responden tergolong bekerja sebagai 'lainnya' (IRT dan mahasiswa) yaitu 171 orang $(59,4 \%)$ dan yang paling sedikit ialah pegawai swasta 27 orang $(9,4 \%)$ (Tabel 3$)$.

Berdasarkan status pernikahan, sebagian besar responden berstatus 
Menikah yaitu 182 orang $(63,2 \%)$ dan Belum Menikah yaitu 106 orang (36,8\%) (Tabel 4).

Tabel 2. Karakteristik berdasarkan pendidikan

\begin{tabular}{lcc}
\hline Pendidikan & N & \% \\
\hline SD & 3 & 1,0 \\
SMP & 16 & 5,6 \\
SMA & 151 & 52,4 \\
Perguruan Tinggi & 118 & 41,0 \\
Total & 288 & 100 \\
\hline
\end{tabular}

Tabel 3. Karakteristik berdasarkan pekerjaan

\begin{tabular}{lcc}
\hline Pekerjaan & N & \% \\
\hline Pegawai Swasta & 27 & 9,4 \\
Pegawai Negeri & 47 & 16,3 \\
Wiraswasta & 43 & 14,9 \\
Lainnya & 171 & 59,4 \\
Total & 288 & 100 \\
\hline
\end{tabular}

Tabel 4. Karakteristik berdasarkan status pernikahan

\begin{tabular}{lcc}
\hline \multicolumn{1}{c}{$\begin{array}{c}\text { Status } \\
\text { pernikahan }\end{array}$} & $\mathbf{N}$ & $\mathbf{\%}$ \\
\hline Belum menikah & 106 & 36,8 \\
Menikah & 182 & 63,2 \\
Total & 288 & 100 \\
\hline
\end{tabular}

Responden yang memiliki tingkat pengetahuan baik tentang kanker leher rahim sebesar 141 orang (49\%), berpengetahuan cukup 132 orang $(45,8 \%)$ dan kurang 15 orang $(5,2 \%)$. Dengan demikian responden yang memiliki tingkat pengetahuan baik lebih banyak dari pada responden yang memiliki tingkat pengetahuan cukup dan kurang. Berdasarkan data didapatkan sebagian besar responden di Puskesmas Bahu memiliki tingkat pengetahuan baik sebanyak 55 orang $(57,3 \%)$, kemudian sebagian besar responden di Puskesmas Tuminting memiliki pengetahuan baik sebanyak 47 orang (49\%), sedangkan responden di Puskesmas Wenang sebagian besar memiliki pengetahuan cukup yaitu sebanyak 47 orang (49\%) (Tabel 5).

Sebagian besar kelompok usia responden yang memiliki tingkat pengetahuan baik ialah usia 30-39 tahun yaitu sebanyak 53 orang $(18,4 \%)$. Sebagian besar responden yang memiliki tingkat pengetahuan cukup ialah yang berusia 2029 tahun yaitu sebanyak 63 orang. Responden yang paling sedikit memiliki tingkat pengetahuan kurang ialah usia $<20$ tahun yaitu sebanyak 1 orang $(0,3 \%)$. Hasil uji statistik menunjukkan adanya hubungan bermakna antara usia dan tingkat pengetahuan $(P=0,042)$ (Tabel 6).

Responden dengan tingkat pendidikan Perguruan Tinggi sebagian besar memiliki tingkat pengetahuan baik yaitu sebanyak 64 orang $(22,2 \%)$. Responden yang berpendidikan SMA sebagian besar memiliki tingkat pengetahuan cukup yaitu sebanyak 76 orang $(26,4 \%)$. Hasil uji statistik menunjukkan adanya hubungan bermakna antara tingkat pendidikan dan tingkat pengetahuan $(P=0,002)$ (Tabel 7).

Responden yang bekerja sebagai Lainnya (IRT dan mahasiswa) sebagian besar memiliki tingkat pengetahuan baik yaitu sebanyak 86 orang (29,9\%). Responden yang bekerja sebagai wiraswasta sebagian besar memiliki tingkat pengetahuan cukup yaitu sebanyak 24 orang $(8,3 \%)$. Responden yang bekerja sebagai pegawai negeri memiliki tingkat pengetahuan baik yaitu sebanyak 28 orang $(9,7 \%)$, sedangkan responden yang bekerja sebagai pegawai swasta sebagian besar memiliki pengetahuan cukup yaitu sebanyak 15 orang $(5,2 \%)$. Hasil uji statistik menunjukkan bahwa tidak terdapat hubungan bermakna antara pekerjaan dan tingkat pengetahuan $(P=0,249)$ (Tabel 8).

Sebagian besar responden yang memiliki tingkat pengetahuan baik ialah responden yang sudah menikah yaitu sebanyak 94 orang $(32,6 \%)$, sedangkan sebagian responden yang belum menikah memiliki tingkat pengetahuan cukup yaitu sebanyak 54 orang $(18,8 \%)$. Hasil uji statistik menunjukkan bahwa tidak terdapat hubungan bermakna antara status pernikahan dan tingkat pengetahuan $(P=0,414)$ (Tabel 9). 
Prayogo, Wantania, Wagey: Tingkat pengetahuan wanita usia reproduksi ...

Tabel 5. Tingkat pengetahuan tentang kanker leher rahim

\begin{tabular}{lcccc}
\hline Tingkat pengetahuan & \multicolumn{3}{c}{ Jumlah - Persentase (\%) } & Total \\
\hline & Kurang & Cukup & Baik & \\
Puskesmas Bahu & $0(0 \%)$ & $41(42,7 \%)$ & $55(57,3 \%)$ & $96(100 \%)$ \\
Puskesmas Tuminting & $5(5,2 \%)$ & $44(45,8 \%)$ & $47(49,0 \%)$ & $96(100 \%)$ \\
Puskesmas Wenang & $10(10,4 \%)$ & $47(49,0 \%)$ & $39(40,6 \%)$ & $96(100 \%)$ \\
Total & $15(5,2 \%)$ & $132(45,8 \%)$ & $141(49,0 \%)$ & $288(100 \%)$ \\
\hline
\end{tabular}

Tabel 6. Tingkat pengetahuan berdasarkan usia

\begin{tabular}{cccccc}
\hline Usia (tahun) & \multicolumn{2}{c}{ Tingkat pengetahuan } & Total & $\boldsymbol{P}$ \\
& Kurang & Cukup & Baik & & \\
\hline & $\mathrm{N} \%$ & $\mathrm{~N} \%$ & $\mathrm{~N} \%$ & $\mathrm{~N} \%$ & \\
$<20$ & $1(0,3)$ & $11(3,8)$ & $10(3,5)$ & $22(7,6)$ & 0,042 \\
$20-29$ & $5(1,7)$ & $63(21,9)$ & $44(15,3)$ & $112(38,9)$ & \\
$30-39$ & $7(2,4)$ & $28(9,7)$ & $53(18,4)$ & $88(30,6)$ & \\
$>40$ & $2(0,7)$ & $30(10,4)$ & $34(11,8)$ & $66(22,9)$ & \\
Total & $15(5,2)$ & $132(45,8)$ & $141(49,0)$ & $288(100)$ & \\
\hline
\end{tabular}

Tabel 7. Tingkat pengetahuan berdasarkan pendidikan

\begin{tabular}{lccccc}
\hline Pendidikan & \multicolumn{2}{c}{ Tingkat pengetahuan } & Total & $P$ \\
& Kurang & Cukup & Baik & & \\
\hline & N $\%$ & N $\%$ & N \% & N \% & \\
SD & $1(0,3)$ & $1(0,3)$ & $1(0,3)$ & $3(1,0)$ & 0,002 \\
SMP & $2(0,7)$ & $11(3,8)$ & $3(1,0)$ & $16(5,6)$ & \\
SMA & $2(0,7)$ & $76(26,4)$ & $73(25,3)$ & $151(52,4)$ & \\
Perguruan tinggi & $10(3,5)$ & $44(15,3)$ & $64(22,2)$ & $118(41,0)$ & \\
Total & $15(5,2)$ & $132(45,8)$ & $141(49,0)$ & $288(100)$ & \\
\hline
\end{tabular}

Tabel 8. Tingkat pengetahuan berdasarkan pekerjaan

\begin{tabular}{lccccc}
\hline Pekerjaan & \multicolumn{2}{c}{ Tingkat Pengetahuan } & Total & $\boldsymbol{P}$ \\
& Kurang & Cukup & Baik & & \\
\hline & $\mathrm{N} \%$ & $\mathrm{~N} \%$ & $\mathrm{~N} \%$ & $\mathrm{~N} \%$ & \\
Pegawai swasta & $2(0,7)$ & $15(5,2)$ & $10(3,5)$ & $27(9,4)$ & 0,249 \\
Pegawai Negeri & $4(1,4)$ & $15(5,2)$ & $28(9,7)$ & $47(16,3)$ & \\
Wiraswasta & $2(0,7)$ & $24(8,3)$ & $17(5,9)$ & $43(14,9)$ & \\
Lainnya & $7(2,4)$ & $78(27,1)$ & $86(29,9)$ & $171(59,4)$ & \\
Total & $15(5,2)$ & $132(45,8)$ & $141(49,0)$ & $288(100)$ & \\
\hline
\end{tabular}

Tabel 9. Tingkat pengetahuan berdasarkan status pernikahan

\begin{tabular}{|c|c|c|c|c|c|}
\hline \multirow[t]{2}{*}{ Status pernikahan } & \multicolumn{3}{|c|}{ Tingkat pengetahuan } & \multirow[t]{2}{*}{ Total } & \multirow[t]{2}{*}{$P$} \\
\hline & Kurang & Cukup & Baik & & \\
\hline & $\mathrm{N} \%$ & $\mathrm{~N} \%$ & $\mathrm{~N} \%$ & $\mathrm{~N} \%$ & \\
\hline Belum menikah & $5(1,7)$ & $54(18,8)$ & $47(16,3)$ & $106(36,8)$ & 0,414 \\
\hline Menikah & $10(3,5)$ & $78(27,1)$ & $94(32,6)$ & $182(63,2)$ & \\
\hline Total & $15(5,2)$ & $132(45,8)$ & $141(49,0)$ & $288(100)$ & \\
\hline
\end{tabular}


BAHASAN

\section{Gambaran tingkat pengetahuan}

Dari 288 responden terdapat sebanyak 141 orang (49\%) berpengetahuan baik, 132 orang $(45,8 \%)$ berpengetahuan cukup, dan 15 orang $(5,2 \%)$ yang berpengetahuan kurang. Hasil penelitian ini tidak sejalan dengan penelitian yang dilakukan oleh Oktaviani $^{8}$ dengan hasil bahwa mayoritas responden memiliki kategori pengetahuan cukup sebanyak 45 orang $(60,8 \%)$.

Pengetahuan merupakan hasil dari tahu dan ini terjadi setelah orang melakukan penginderaan terhadap suatau objek tertentu. Penginderaan terjadi melalui pancaindera manusia, yakni indra penglihatan, penciuman, rasa dan raba. Sebagian besar pengetahuan manusia diperoleh melalui mata dan telinga. $^{9}$

Pengetahuan responden mengenai kanker leher rahim tersebut disebabkan karena baiknya pelayanan informasi kesehatan yang responden terima di Puskesmas. Hal tersebut dikarenakan penyuluhan atau pendidikan kesehatan dilakukan secara kontinyu atau terus menerus.

\section{Hubungan tingkat pengetahuan dengan usia}

Data yang didapatkan di Puskesmas Bahu, Tuminting dan Wenang sebanyak 288 responden. Responden yang berusia 30-39 sebagian besar memiliki tingkat pengetahuan baik yaitu sebanyak 53 responden $(18,4 \%)$, sedangkan sebagian besar responden yang memiliki tingkat pengetahuan cukup ialah yang berusia 20 29 tahun yaitu sebanyak 44 orang $(15,3 \%)$. Hasil uji statistik menunjukkan bahwa terdapat hubungan bermakna antara usia dan tingkat pengetahuan $(P=0,042)$. Penelitian yang dilakukan oleh Hidayah ${ }^{10}$ mendapatkan sebagian besar responden yang berusia $31-35$ tahun (40\%) memiliki tingkat pengetahuan baik tentang kanker leher rahim. Pada penelitiannya juga didapatkan hubungan antara tingkat pengetahuan kanker leher rahim dan usia. ${ }^{10}$ Pengetahuan juga dipengaruhi oleh usia, karena dapat memengaruhi daya tangkap dan pola pikir seseorang. Semakin bertam- bah usia akan semakin berkembang pula daya tangkap dan pola pikirnya. ${ }^{11}$

\section{Hubungan tingkat pengetahuan dengan pendidikan}

Pada penelitian ini responden dengan tingkat pendidikan Perguruan Tinggi sebagian besar memiliki tingkat pengetahuan baik yaitu sebanyak 64 orang $(22,2 \%)$. Responden yang berpendidikan SMA sebagian besar memiliki tingkat pengetahuan cukup yaitu sebanyak 76 orang (26,4\%). Hasil uji statistik menunjukkan adanya hubungan bermakna antara tingkat pendidikan dan tingkat pengetahuan $(P=0,002)$. Hasil penelitian ini selaras dengan penelitian yang dilakukan oleh $\mathrm{Hadi}^{12}$ di Iran terhadap 402 responden, dan mendapatkan sebanyak 80 orang (19,9\%) yang berpendidikan SMA. Dalam hasil penelitiannya disebutkan terdapat hubungan antara pendidikan dan tingkat pengetahuan tentang kanker leher rahim. Sejalan dengan penelitian yang dilakukan Soebarkah $^{13}$ yang menyatakan bahwa semakin tinggi pendidikan semakin tinggi juga pengetahuan seseorang.

Menurut Wawan dan Dewi, ${ }^{14}$ semakin tinggi tingkat pendidikan seseorang, maka semakin mudah dalam menerima hal-hal baru sehingga akan lebih mudah pula untuk menyelesaikan hal-hal baru tersebut. Pendidikan seseorang memengaruhi cara pandang. Masyarakat yang berpendidikan tinggi akan lebih mudah menerima informasi dari penyuluhan yang diberikan dan lebih cepat merubah sikap dalam kehidupan sehari-hari. Menurut Nursalam, ${ }^{15}$ semakin tinggi tingkat pendidikan seseorang, maka semakin mudah pula menerima informasi sehingga makin banyak pula pengetahuan yang dimiliki. Jadi, semakin tinggi pendidikan seseorang semakin tinggi pula pengetahuan tentang kanker leher rahim.

\section{Hubungan tingkat pendidikan dengan pekerjaan}

Pada penelitian ini responden yang bekerja sebagai 'Lainnya' (IRT dan mahasiswa) sebagian besar memiliki 
tingkat pengetahuan baik yaitu sebanyak 86 orang $(29,9 \%)$. Responden yang bekerja sebagai wiraswasta sebagian besar memiliki tingkat pengetahuan cukup yaitu sebanyak 2 orang $(8,3 \%)$. Selanjutnya responden yang bekerja sebagai pegawai negeri memiliki tingkat pengetahuan baik yaitu sebanyak 28 orang $(9,7 \%)$, sedangkan responden yang bekerja sebagai pegawai swasta sebagian besar memiliki pengetahuan cukup yaitu sebanyak 15 orang $(5,2 \%)$. Hasil uji statistik menunjukkan bahwa tidak terdapat hubungan bermakna antara pekerjaan dan tingkat pengetahuan $(P=0,249)$. Hasil penelitian ini tidak sejalan dengan teori dari Mubarak ${ }^{16}$ yang menyatakan bahwa lingkungan pekerjaan dapat menjadikan seseorang memperoleh pengalaman dan pengetahuan baik secara langsung maupun tidak langsung.

\section{Hubungan tingkat pengetahuan dengan status pernikahan}

Pada penelitian ini responden yang memiliki tingkat pengetahuan baik ialah responden yang sudah menikah yaitu sebanyak 94 orang (32,6\%), sedangkan sebagian responden yang belum menikah memiliki tingkat pengetahuan cukup yaitu sebanyak 54 orang $(18,8 \%)$. Hasil uji statistik menunjukkan bahwa tidak terdapat hubungan bermakna antara status pernikahan dan tingkat pengetahuan $(P=0414)$. Status pernikahan tidak menjamin seseorang memiliki pengetahuan baik, tergantung dari minat seseorang pada suatu informasi. $^{17}$

\section{SIMPULAN}

Dari hasil penelitian dapat disimpulkan bahwa terdapat hubungan bermakna antara usia dan pendidikan dengan tingkat pengetahuan. Tidak terdapat hubungan antara pekerjaan dan status pernikahan dengan tingkat pengetahuan.

\section{SARAN}

Disarankan bagi tenaga professional kesehatan untuk lebih giat lagi mensosialisasikan tentang penyakit kanker leher rahim ataupun penyakit lainnya, agar masyarakat dapat mengetahui gejala dan bahaya yang dapat terjadi.

Disarankan untuk penelitian lanjut dengan jumlah responden yang lebih banyak sehingga dapat dilakukan generalisasi pada populasi yang lebih baik.

\section{DAFTAR PUSTAKA}

1. Setiati S Idrus A. Aru W, Marcellus S, Bambang S, Ari Fahrial S, editors. Ilmu Penyakit Dalam Jilid III. Jakarta: Internal Publishing, 2014; p. 2052.

2. Kanker serviks. [cited 2017 Aug 23]. Available from: http://epirimts.uny.ac.id/ 35315/1/BAB\%201.pdf

3. American Cancer Society. Alcohol use and cancer. 2014. [cited 2017 Aug 23]. Available from: http://www.cancer.org/ acs/groups/content/@ healtpromotions/do cuments/acsq-017622.pdf

4. American Cancer Society. Cervical cancer prevention and early detection. 2014 [cited 2017 Aug 23]. Available from: http://www.cancer.org/acs/groups/cid/do cuments/webcontent/003157-pdf.pdf

5. Adi TN. Wanita dan deteksi dini kanker serviks(studi korelasi antara sikap dan norma subjektif dengan intensi wanita dewasa dalam pemeriksaan deteksi dini kanker serviks). ActadiurnA. 2011;7:156.

6. Retno RS. Gambaran karakteristik ibu yang mengalami kanker serviks dirumah sakit umum daerah (RSUD) penambahan senopati bantul Yogyakarta [Karya tulis ilmiah]. Yogyakarta: Sekolah Tinggi Ilmu Kesehatan Jendral Achmad Yani Yogyakarta; 2016.

7. Notoadmodjo S. Metodologi Penelitian Kesehatan. Jakarta: Rineka Cipta, 2007; p. 127-8.

8. Cherin O. Tingkat pengetahuan wanita usia subur tentang kanker serviks di Dukuh Kajon Desa Nguntoronadi Kecamatan Nguntoronadi Kabupaten Magetan [Skripsi]. Surakarta: Sekolah Tinggi Ilmu Kesehatan Husada; 2013.

9. Notoadmodjo S. Ilmu Kesehatan Masyarakat Prinsip-Prinsip Dasar. Jakarta: Rineka Cipta, 2003.

10. Hidayah L. Gambaran tingkat pengetahuan wanita usia subur tentang Ca serviks di Pondok Pesantren Islam Al-Mukmin Sukoharjo [Skripsi]. Surakarta: STIKES Muhammadiyah, 2013. 
11. Notoadmodjo S. Kesehatan Masyarakat Ilmu dan Seni. Jakarta: Rineka Cipta, 2007.

12. Hadi N. Knowledge attitude and practice of women Shiraz about cervical cancer and pap smear. 2009 cited 2017 Nov 26]. Available from: http://www.sid.ir/en VEWSSID/J pdf/118920100303.pdf

13. Soebarkah. Hubungan antara tingkat pengetahuan wanita tentang kanker serviks dengan angka kejadian kanker serviks di Poli Kebidanan dan Kandungan RSUD DR. Saiful Anwae Malang. Malang: FKUB. [cited 2017
Nov 26]. Available from: http://fk.ub.ac/ artikel/id

14. Wawan A, Dewi, M. Teori dan pengukuran pengetahuan, sikap dan perilaku manusia. Yogyakarta: Nuha Medika, 2010.

15. Narusalam. Manajemen Keperawatan. Jakarta: Salemba Medika, 2015.

16. Mubarak W. Promosi Kesehatan Sebuah Pengantar Proses Belajar Mengajar dalam Pendidikan. Yogyakarta: Graha Ilmu, 2007.

17. Buchori, Muchtar. Transformasi Pendidikan. Jakarta: Sinar Harapan, 2006. 